\title{
Development of Red and Ox Game for Android Mobile Phone as Learning Media for Balancing Redox Equations
}

\author{
Ryan Hendra Cahyadhi" ${ }^{* 1}$, Achmad Lutfi \\ ${ }^{1}$ Pendidikan Kimia, Fakultas Matematika dan Ilmu Pengetahuan Alam, Universitas Negeri Surabaya \\ *Corresponding author: achmadlutfi@unesa.ac.id
}

\begin{abstract}
Aim of this study was to discover the feasiblity of Red and Ox Game for android mobile phone as learning media for Balancing Redox Equations. This game feasibility based on 3 criteria among them are validity, practicabilty and effectiveness. This study using Research and Development methods which consist of 3 main step (early study, development and teoritical validity, and game test itself). Result of this game validity is $88,63 \%$ from 3 different validator. Practicabilty result for this game based on student's responses is $87,71 \%$ with $84 \%$ of it student completed the whole game level. And effectiveness from this game result that $96 \%$ of this class surpassed standard score and paired $t$-test showed that after using this game there is difference between pretest and posttest which mean that this game is effective. Based on those 3 criteria, this game is proper as learning media for Balancing Redox Equations.
\end{abstract}

Keywords: Redox, Game, Android, Learning

\section{PENDAHULUAN}

Pada abad 21 saat ini para peserta didik memperoleh banyak tantangan karena pesatnya perkembangan seperti ilmu pengetahuan, sosial budaya, ekonomi, agama dan teknologi. Dengan begitu banyaknya tantangan yang diperoleh, para peserta didik dituntut menguasai teknologi informasi, berkomunikasi dan berkolaborasi. Didukung dengan berkembangnya teknologi informasi yang semakin maju ini, sistem pendidikan harus mempersiapkan pola yang sesuai dengan perkembangan zaman. Sebuah usaha yang digunakan untuk mewujudkan suasana belajar agar berkembangnya potensi para peserta didik merupakan definisi dari pendidikan (Depdiknas, 2003). Kedudukan dan peranan dari pendidikan itu sendiri sangat penting sehingga perlu adanya perhatian khusus dari lapisan masyarakat dan pemerintah sebab melalui pendidikan dapat dibentuk kepribadian anak dan potensinya. Oleh karena itu, Perbaikan dari pendidikan itu sendiri dilakukan dari waktu ke waktu dituntut untuk terus diadakan perbaikan sehingga tujuan yang diharapkan mampu tercapai.

Salah satu upaya yang telah dilakukan untuk menyesuaikan pola pembelajaran yang sesuai dengan perkembangan zaman yaitu dengan adanya perubahan kurikulum pada jangka waktu tertentu. Hal tersebut telah dilakukan oleh Kemendikbud yang merubah kurikulum KTSP menjadi Kurikulum 2013. Penyelenggaraan proses pembelajaran pada satuan pendidikan dilakukan sedemikian rupa supaya sesuai dengan bakat dan minat para peserta didik (Kementerian Pendidikan dan Kebudayaan, 2016) tetapi pada beberapa sekolah masih banyak yang menerapkan model pembelajaran dengan model lama (konvensional). Model pembelajaran konvensional memiliki ciri di mana proses pembelajaran berpusat pada guru bukan peserta didik, ditambah pengelolaan kelas yang menggunakan media mainstream sehingga peserta didik mudah bosan karena tidak terciptanya pembelajaran yang menyenangkan. Ciri pembelajaran yang menyenangkan ialah lingkungan belajar-mengajar yang rileks dan mampu membuat para peserta didik percaya diri dalam mencapai keberhasilannya (Jauhar, 2010).

Kimia merupakan salah satud dari banyaknya mata pelajaran yang diajarkan di Sekolah Menengah Atas, dan merupakan salah satu dari beberapa cabang ilmu yang penting 
dari ilmu pengetahuan alam. Mata pelajaran kimia meupakan ilmu yang mempelajari struktur, sifat, dan perubahan materi. Berkaitan dengan struktur zat dan adanya konsep-konsep yang terkandung dalam ilmu kimia yang kompleks, kimia dianggap sebagai pelajaran yang sulit bagi banyak peserta didik. Salah satu materi kimia adalah materi reaksi reduksi dan oksidasi. Materi tersebut merupakan pembahasan dan konsep yang harus dikuasai oleh peserta didik karena menjadi materi prasyarat pada materi selanjutnya yaitu materi elektrokimia. Elektrokimia merupakan materi yang mempelajari tentang perpindahan elektron yang terjadi pada sebuah media penghantar listrik (elektroda). Elektroda-elektroda tersebut mengalami perpindahan elektron. Pada reaksi reduksi terjadi peristiwa pengangkapan elektron sedangkan reaksi oksidasi merupakan peristiwa pelepasan elektron yang terjadi pada elektroda pada elektroda pada materi elektrokimia. Sel elektrolisis dan sel volta merupakan hasil terapan dari sel elektrokimia yang berdasarkan pada materi reaksi redoks (Dingrando, et.all., 2004). Apabila peserta didik mengalami kesulitan pada materi ini, maka mereka akan mengalami kesulitan pada materi selanjutnya.

Berdasarkan angket pra penelitian yang disebarkan kepada masing-masing 20 orang peserta didik kelas XII dari MAN 1 Gresik kelas XII, SMA Muhammadiyah 1 Surabaya kelas XII dan MAN Surabaya menunjukkan bahwa sebesar $63,33 \%$ peserta didik menyatakan materi reaksi reduksi oksidasi sulit. Materi yang dirasa sulit oleh mereka dapat teratasi dengan berbagai alternatiif yang ada, salah satunya dengan menggunakan media pembelajaran. Media adalah segala hal yang mampu menyampaikan pesan yang diharapkan dari pengirim kepada penerima sehingga dapat merangsang pikiran, perasaan, perhatian, serta minat peserta didik sedemikian rupa sehingga proses belajar dapat terjadi (Sardiman, 2011). Namun, berdasarkan hasil angket pra penelitian yang disebarkan ke kepada 20 orang peserta didik dari MAN 1 Gresik kelas XII dan 20 orang peserta didik SMA Muhammadiyah 1 Surabaya kelas XII menunjukkan bahwa di kelas-kelas masih menggunakan media pembelajaran berupa papan tulis. Padahal terdapat beberapa alternatif lain media pembelajaran, salah satu dari banyaknya alternatif yang ada ialah media pembelajaran yang dikemas sedemikian rupa dalam bentuk permainan. Kelebihan dari media permbelajaran tersebut (Sardiman, 2011) diantaranya ialah menyenangkan untuk dilakukan, menghibur dan menarik. Sejalan dengan perkembangan teknologi, mulai banyak permainan-permainan menarik, menghibur dan menyenangkan. Hal tersebut juga berdampak pada mulai berkembangnya permainan yang memberikan dampak signifikan terhadap proses penyempurnaan pembelajaran (Nordby, et, all., 2016). Didudukung oleh data awal penelitian yang menunjukkan sebanyak $95 \%$ peserta didik merasa apabila belajar materi menggunakan media bersarana handphone berupa permainan akan menarik.

Selama ini telah dikembangkan permainan sebagai media pembelajaran. Seperti pada penelitian tentang pengembangan permainan serupa (Slamet, 2016, Rahmawati, 2018) yang menyatakan bahwa tujuan dibuat permainan bersarana smartphone yang berbasis android adalah melibatkan para peserta didik ke dalam proses belajar secara aktif dan mampu menciptakan proses pembelajaran yang menarik, memotivasi peserta didik untuk belajar lebih giat supaya mampu meningkatkan hasil belajar mereka. Memanfaatkan perkembangan ilmu pengetahuan dan teknologi untuk memodifikasi media pembelajaran khususnya bagi materi kimia yang abstrak (Sari, 2017). Media permainan yang dihasilkan dapat dioperasikan di smartphone yang mana mudah untuk digunakan.

Permainan ini bercerita tentang karakter utama "Red" yang bertualang ke berbagai dimensi untuk mencari sebuah artefak. permainan ini memiliki 3 level dan pada tiaptiap levelnya memiliki fokus isi tersendiri. Cara memainkannya, para pemain harus belajar terlebih dahulu pada bagian "belajar" di menu awal, setelah itu para pemain dapat memilih menu "main", dan dapat memilih level. Tiap level harus diselesaikan untuk membuka level selanjutnya. Pada tiap-tiap level pemain harus memperoleh 6 kunci dari total 8 kunci yang tersedia, cara memperoleh kuncinya adalah dengan menjawab soal yang ada pada masingmasing kotak pertanyaan dan mengalahkan musuh yang ada, terdapat bantuan berupa materi dan tambahan "nyawa" pemain, materi disediakan dalam bentuk ikon "buku" dan bantuan "nyawa" tersedia dalam bentuk kotak 
nyawa, kedua bantuan tersebut dapat "dibeli" menggunakan "koin" dengan harga tertentu, koin-koin tersebut dapat diperoleh secara gratis karena tersebar. Tiap level juga memiliki waktu penyelesaian tertentu, sehingga pemain harus bisa menyelesaikan level tersebut sebelum waktunya habis.

Berdasarkan uraian-uraian
maka pebelumnya,
melakukan penelitian pengembangan Permainan Red dan Ox Berbasis Android Sebagai Media Pembelajaran Pada Materi Penyetaraan Reaksi Redoks yang bertujuan untuk mengetahui kelayakan dari permainan tersebut.

\section{METODE}

Metode yang diambil dalam penelitian penelitian ini ialah metode Research and Development (R\&D) oleh Sukmadinata (2016) yang memodifikasi langkah-langkah penelitian dan pengembangan dari Borg and Gall. Karena penelitian ini digunakan untuk mencari tahu kelayakan dari permainan yang akan digunakan sebagai media pembelajaran maka dilaksanakan sampai tahap uji coba permainan.

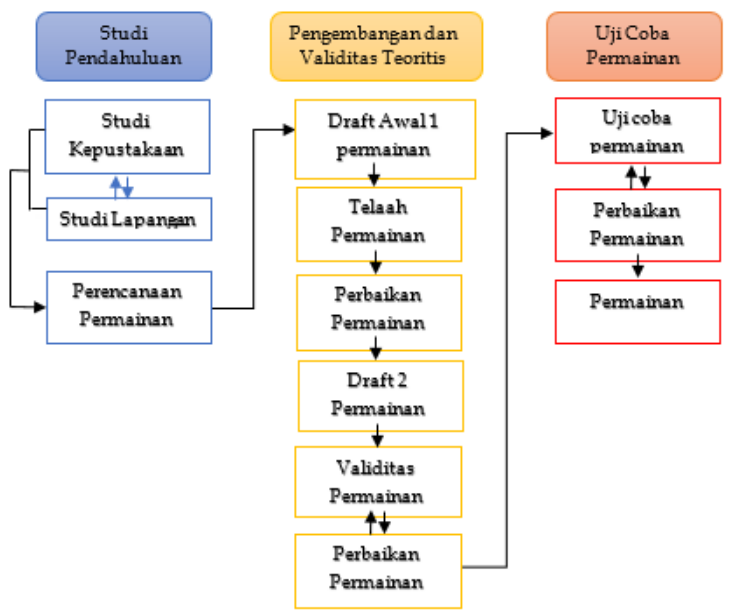

\section{Gambar 1 Tahapan Penelitian dan Pengembangan Modifikasi Sukmadinata}

Seperti yang tertera pada Gambar 1, pada tahap studi pendahuluan terdapat beberapa langkah-langkah yang digunakan untuk mempelajari kajian mengenai teori-teori yang berkaitan dengan produk yang akan dirancang kemudian dikembangkan. Kemudian dilakukan proses pengumpulan data yang berkaitan dengan perencanaan produk. Pada akhir tahap studi pendahuluan ini kemudian diharapkan dapat menyusun draft awal permainan yang akan dirancang kemudian dikembangkan. Permainan ini digunakan sebagai media pembelajaran pada materi reaksi reduksi dan oksidasi. Draft produk kemudian dilakukan proses penelaahan dan validasi oleh penelaah dan para validator untuk disempurnakan sesuai dengan saran yang diberikan.

Tahap selanjutnya bertujuan agar dapat dihasilkannaya permainan Red dan Ox yang dapat dipergunakan sebagai media dalam pembelajaran berdasarkan hasil telaah dan validasi yang kemudian akan diujicobakan kepada peserta didik yang belum mendapatkan materi penyetaraan reaksi redoks kelas XII SMA. Draft awal 1 permainan kemudian ditelaah oleh seorang dosen kimia. Penelaah akan menelaah permainan yang selanjutnya akan dilakukan validasi. Perbaikan permainan dilakukan sesuai dengan saran dan masukan dari penelaah sehingga didapatkan draft 2 permainan. Validasi permainan dilakukan setelah didapatkan draft 2 permainan. Validasi dilakukan oleh 3 orang validator yang meninjau validitas dari dua hal yakni dari segi isi dan konstruk. Kemudian apabila terdapat skor yang belum memenuhi kriteria permainan dilakukan perbaikan permainan. Kemudian hasil perbaikan dilakukan validasi kembali untuk mengetahui validitas dari permainan Red dan Ox sebagai media pembelajaran. Hasil validitas permainan Red dan Ox diakumulasikan menggunakan perhitungan sebagai berikut.

$$
\begin{aligned}
& \mathrm{P}(\%)=\frac{\sum \text { skor yang diperoleh }}{\text { skor kriterium }} \times 100 \% \\
& \text { Dengan keterangan: }
\end{aligned}
$$

Skor kriterium $=$ skor tertinggi tiap item $\times$ jumlah item $\times$ jumlah validator. Hasil analisis yang diperoleh dari lembar validitas kemudian digunakan untuk mengetahui validitas permainan. Setelah diperoleh skor dari lembar validitas, kemudian skor tersebut diinterpretasikan dengan besar persentase penilaian (Riduwan, 2012) yang ada pada tabel berikut.

Tabel 1 Interpretasi Validitas Skala Likert

\begin{tabular}{cc}
\hline Persentase $(\%)$ & Penilaian \\
\hline $0-20$ & Sangat kurang \\
\hline $21-40$ & Kurang \\
\hline $41-60$ & Cukup \\
\hline $61-80$ & Valid \\
\hline $81-100$ & Sangat valid \\
\hline
\end{tabular}


Permainan Red dan Ox pada materi reaksi reduksi dan oksidasi dikatakan valid apabila persentasenya $\geq 61 \%$ atau termasuk dalam kategori valid atau sangat valid dan pada tiaptiap aspeknya diperoleh skor $\geq 3$.

Kemudian pada tahap uji coba permainan, Produk hasil revisi dan validasi selanjutnya diujicobakan pada peserta didik tingkat SMA yang belum mendapatkan materi reaksi redoks kelas XII di SMAN 22 Surabaya. Dalam pelaksanaan uji coba permainan, dilakukan uji kepraktisan dan keefektifan. Uji coba permainan pada tahap ini menggunakan sistem one group pretest-postest design, yaitu sebeleum peserta didik melakukan kegiatan pembelajaran menggunakan permainan akan diberikan pretest berupa rangkaian soal mengenai materi reaksi reduksi dan oksidasi. Kemudian, dilakukan postest dimana soal yang diberikan sama untuk melihat dampak yang didapatkan oleh peserta didik setelah mereka menggunakan permainan. Pada angket respon peserta didik dan lembar pengamatan peserta didik dilakukan pemberian skor (Riduwan, 2012). Pemberian skor dilakukan berdasarkan skor pada tabel berikut.

\section{Tabel 2 Kriteria Skala Guttman}

\begin{tabular}{ccc}
\hline Jawaban & $\begin{array}{c}\text { Skor untuk } \\
\text { pernyataan } \\
\text { positif }\end{array}$ & $\begin{array}{c}\text { Skor untuk } \\
\text { pernyataan } \\
\text { negatif }\end{array}$ \\
\hline Ya & 1 & 0 \\
\hline Tidak & 0 & 1 \\
\hline
\end{tabular}

Data yang diperoleh akan dihitung menggunakan cara perhitungan sebagai berikut.

$$
\mathrm{P}(\%)=\frac{\sum \text { skor jawaban peserta didik }}{\text { jumlah peserta didik }} \times 100 \%
$$

Hasil perhitungan lembar angket respon dan lembar pengamatan peserta didik yang telah diperoleh kemudian skor tersebut diinterpretasikan dengan besar persentase penilaian (Riduwan, 2012) yang ada pada tabel berikut.

Tabel 3 Interpretasi Kepraktisan Skala Likert

\begin{tabular}{cc}
\hline Persentase $(\%)$ & Penilaian \\
\hline $0-20$ & $\begin{array}{c}\text { Sangat kurang } \\
\text { praktis }\end{array}$ \\
\hline $21-40$ & Kurang praktis \\
\hline
\end{tabular}

\begin{tabular}{cc}
\hline $41-60$ & Cukup praktis \\
\hline $61-80$ & Praktis \\
\hline $81-100$ & Sangat praktis \\
\hline
\end{tabular}

Pada kategori yang ada dalam tabel 3 , pengembangan permainan Red dan Ox pada materi reaksi reduksi dan oksidasi dikatakan praktis apabila persentasenya $\geq 61 \%$ atau termasuk dalam kategori praktis atau sangat praktis.

Keefektifan dinilai berdasarkan data hasil pretest dan posttest peserta didik. Data tersebut digunakan untuk menganalisis pemahaman peserta didik terhadap materi reaksi reduksi dan oksidasi. Soal-soal yang digunakan berupa pilihan ganda. Pemberian tes digunakan untuk mengetahui penguasaan konsep terhadap materi pembelajaran yang disajikan melalui permainan yang dikembangkan Analisis data pemahaman konsep peserta didik menggunakan kriteria ketuntasan individu dan klasikal peserta didik. Data hasil pretest dan posttest diuji normalitas dan uji t terlebih dahulu untuk menguji bahwa data tersebut tersebut terdistribusi normal dan uji $\mathrm{t}$ digunakan untuk mengetahui adanya perbedaan pada skor pretest dan postest. Kedua uji tersebut menggunakan software SPSS. Hipotesis yang digunakan untuk menguji normalitas adalah sebagai berikut.

$H_{0}$ : Data tes berasal dari populasi yang berdistribusi normal

$H_{1}$ : Data tes berasal dari populasi yang berdistribusi tidak normal

Untuk menguji hipotesis dari uji normalitas tdigunakan P-Value dengan keterangan sebagai berikut.

$P$-value $>\alpha$, maka $H_{0}$ diterima

$P$-value $<\alpha$, maka $H_{0}$ ditolak

Kemudian digunakan uji Paired Sampel t-test untuk menguji perbedaan pada pretest dan posttest digunakan uji sampel paired t-test dengan hipotesis sebagai berikut.

$H_{0}$ : Tidak terdapat perbedaan rata-rata skor pretest dan posttest

$H_{l}$ : Terdapat perbedaan rata-rata skor pretest dan posttest

Untuk menguji hipotesis pada Paired Sampel $t$ test digunakan $\mathrm{P}-\mathrm{V}$ alue dengan keterangan sebagai berikut. 
$P$-value $>\alpha$, maka $H_{0}$ diterima

$P$-value $<\alpha$, maka $H_{0}$ ditolak

Untuk mengetahui ketuntasan individu dapat dihitung dengan menggunakan rumus sebagai berikut

$$
=\frac{\sum \text { jawaban benar }}{\text { jumlah soal }} \times 100
$$

Sedangkan untuk mengetahui ketuntasan klasikal dapat dihitung menggunakan rumus sebagai berikut.

\%Ketuntasan Klasikal

$=\frac{\sum \text { peserta didik tuntas }}{\text { jumlah peserta didik }} \times 100 \%$

Didasarkan pada KKM mata pelajaran kimia yang diterapkan, maka ketuntasan individu dikatakan tuntas apabila nilai pesera didik $\geq 75$. Kelas tersebut dapat dinyatakan tuntas secara klasikal apabila didalam kelas tersebut sebanyak $\geq 85 \%$ peserta didik didalamnya tuntas hasil belajarnya.

\section{HASIL DAN PEMBAHASAN}

Hasil penelitian yang telah diperoleh dalam pengembangan permainan Red dan $\mathrm{Ox}$ berbasis android pada materi penyetaraan reaksi reduksi dan oksidasi yakni sebagai berikut.

\section{Studi Pendahuluan}

Pada tahapan studi pendahuluan terdiri atas 3 langkah yakni studi kepustakaan, survei lapangan, dan perencanaan permainan. Pada tahapan ini diperoleh hasil sebesar 63,33\% peserta didik menyatakan materi reaksi reduksi oksidasi sulit. Materi yang dirasa sulit oleh mereka dapat teratasi dengan berbagai alternatiif yang ada, salah satunya dengan menggunakan media pembelajaran. Media adalah segala hal yang mampu menyampaikan pesan yang diharapkan dari pengirim kepada penerima sehingga dapat merangsang pikiran, perasaan, perhatian, serta minat peserta didik sedemikian rupa sehingga proses belajar dapat terjadi (Sardiman, 2011). Namun, berdasarkan hasil angket pra penelitian yang disebarkan ke kepada 20 orang peserta didik dari MAN 1 Gresik kelas XII dan 20 orang peserta didik SMA Muhammadiyah 1 Surabaya kelas XII menunjukkan bahwa di kelas-kelas masih menggunakan media pembelajaran berupa papan tulis. Padahal terdapat beberapa alternatif lain media pembelajaran, salah satu dari banyaknya alternatif yang ada ialah media pembelajaran yang dikemas sedemikian rupa dalam bentuk permainan. Kelebihan dari media permbelajaran tersebut (Sardiman, 2011) diantaranya ialah menyenangkan untuk dilakukan, menghibur dan menarik. Sejalan dengan perkembangan teknologi, mulai banyak permainan-permainan menarik, menghibur dan menyenangkan. Hal tersebut juga berdampak pada mulai berkembangnya permainan komputer dan video yang memberikan dampak signifikan terhadap proses penyempurnaan pembelajaran (Nordby, et, all., 2016). Didudukung oleh data awal penelitian yang menunjukkan sebanyak $95 \%$ peserta didik merasa apabila belajar materi menggunakan media bersarana handphone berupa permainan akan menarik. Selama ini telah dikembangkan permainan sebagai media pembelajaran. Seperti pada penelitian tentang pengembangan permainan serupa (Slamet, 2016, Rahmawati, 2018) yang menyatakan bahwa tujuan dibuat permainan bersarana smartphone yang berbasis android adalah melibatkan para peserta didik ke dalam proses belajar secara aktif dan mampu menciptakan proses pembelajaran yang menarik, memotivasi peserta didik untuk belajar lebih giat supaya mampu meningkatkan hasil belajar mereka. Memanfaatkan perkembangan ilmu pengetahuan dan teknologi untuk memodifikasi media pembelajaran khususnya bagi materi kimia yang abstrak (Sari, 2017). Media permainan yang dihasilkan dapat dioperasikan di smartphone yang mana mudah untuk digunakan.

\section{Pengembangan dan Validitas Teoritis}

Pada tahapan ini dilakukan untuk menghasilkan permainan Red dan Ox yang dapat digunakan sebagai media pembelajaran. Draft awal 1 permainan menghasilkan storyboard yang kemudian ditelaah oleh seorang dosen kimia, kemudian pada proses telaah permainan diperoleh masukan dari penelaah berupa penambahan video dan adanya sebuah reward pada bagian akhir permainan berupa kata-kata penyemangat bagi para peserta didik. Kemudian setelah permainan diperbaiki sesuai masukan dan saran dari penelaah didapatkan draft 2 permainan yang kemudian dilakukan penilaian validitas permainan. Validitas permainan Red dan Ox 
dinilai oleh 3 orang validator. Validitas isi yaitu kemutahiran dan kebenaran konsep dan materi yang disajikan dalam permainan sebagai media pembelajaran sudah benar dan mutahir. Validitas konstruk memiliki konsistensi internal pada permainan sebagai media pembelajaran yang dikembangkan. Validitas isi maupun konstruk tersebut kemudian dijadikan dalam sebuah instrumen yang terdiri dari beberapa aspek (Lutfi, 2014) yang kemudian dinilai oleh para validator, aspek validitas yang masih belum memenuhi kriteria kemudian dilakukan perbaikan, seperti penghapusan outline pada tulisan dan juga perbaikan pada penulisan fasa pada reaksi yang ada pada video dalam permainan. Setelah dilakukan perbaikan didapatkan hasil validitas sesuai tabel 4 .

\section{Tabel 4 Hasil Validitas Permainan}

\begin{tabular}{|c|c|c|c|}
\hline No. & Aspek & $\begin{array}{c}\text { Persentase } \\
(\%)\end{array}$ & Kategori \\
\hline \multicolumn{4}{|c|}{ Validasi Isi } \\
\hline 1 & $\begin{array}{c}\text { Kebenaran } \\
\text { konsep } \\
\text { pengetahuan }\end{array}$ & 80,00 & Valid \\
\hline 2 & Indikator & 86,67 & $\begin{array}{l}\text { Sangat } \\
\text { Valid }\end{array}$ \\
\hline \multicolumn{4}{|c|}{ Validasi Konstruk } \\
\hline 3 & $\begin{array}{c}\text { Ciri ke-IPA- } \\
\text { an }\end{array}$ & 86,67 & $\begin{array}{c}\text { Sangat } \\
\text { Valid }\end{array}$ \\
\hline 4 & $\begin{array}{l}\text { kesesuaian } \\
\text { dengan } \\
\text { karakteristik } \\
\text { siswa }\end{array}$ & 83,33 & $\begin{array}{l}\text { Sangat } \\
\text { Valid }\end{array}$ \\
\hline 5 & $\begin{array}{l}\text { mempunyai } \\
\text { aturan }\end{array}$ & 93,33 & $\begin{array}{l}\text { Sangat } \\
\text { Valid }\end{array}$ \\
\hline 6 & $\begin{array}{c}\text { ada aspek } \\
\text { membimbing }\end{array}$ & 93,33 & $\begin{array}{l}\text { Sangat } \\
\text { Valid }\end{array}$ \\
\hline 7 & $\begin{array}{c}\text { Menantang } \\
\text { dan } \\
\text { melibatkan } \\
\text { peserta didik }\end{array}$ & 86,67 & $\begin{array}{l}\text { Sangat } \\
\text { Valid }\end{array}$ \\
\hline 8 & $\begin{array}{l}\text { Ada standar } \\
\text { keberhasilan }\end{array}$ & 93,33 & $\begin{array}{l}\text { Sangat } \\
\text { Valid }\end{array}$ \\
\hline 9 & $\begin{array}{l}\text { Memberikan } \\
\text { umpan balik }\end{array}$ & 93,33 & $\begin{array}{l}\text { Sangat } \\
\text { Valid }\end{array}$ \\
\hline 10 & $\begin{array}{c}\text { Ada aspek } \\
\text { pengambilan } \\
\text { keputusan }\end{array}$ & 86,67 & $\begin{array}{c}\text { Sangat } \\
\text { Valid }\end{array}$ \\
\hline 11 & Tampilan & 88,89 & $\begin{array}{c}\text { Sangat } \\
\text { Valid }\end{array}$ \\
\hline
\end{tabular}

\begin{tabular}{cccc}
\hline No. & Aspek & $\begin{array}{c}\text { Persentase } \\
(\%)\end{array}$ & Kategori \\
\hline 12 & $\begin{array}{l}\text { Komunikasi } \\
\text { audio visual }\end{array}$ & 90,00 & $\begin{array}{c}\text { Sangat } \\
\text { Valid }\end{array}$ \\
\hline
\end{tabular}

Pada tabel 4 di atas diperoleh hasil validitas isi dan konstruk. Pada aspek validitas isi didapatkan persentase $80 \%$ pada aspek kebenaran konsep yang mana sudah termasuk kategori valid dan persentase $86,67 \%$ pada aspek indikator yang sudah masuk kategori sangat valid, hal ini menunjukkan bahwa dari validitas isi permainan ini sudah valid sebagai media pembelajaran namun terdapat beberapa materi yang perlu ditambahkan. Informasi yang ada pada permainan ini harus benar dikarenakan permainan ini merupakan media yang digunakan sebagai penyalur informasi bagi peserta didik (Danim, 2010).

Pada validitas konstruk skor tertinggi berada apada aspek mempunyai aturan, aspek membimbing, ada standar keberhasilan, memberikan umpan balik yakni pada perentase 93,33\%. Pada aspek mempunyai aturan pada permainan ini terdapat di awal permainan dimana peserta didik harus belajar terlebih dahulu untuk bisa memainkan permainan ini, serta pada awal level permainan terdapat petunjuk yang dapat harus dibaca terlebih dahulu. Aspek membimbing pada permainan ini juga terletak pada menu belajar yang disediakan video, dan juga pada tiap-tiap levelnya terdapat materi yang disesuaikan pada masing-masing levelnya. Standar keberhasilan pada permainan ini jelas, yakni mendapatkan minimal 6 kunci dengan cara menjawab 6 dari 8 pertanyaan-pertanyaan yang ada pada masing-masing levelnya. Umpan balik permainan ini terletak pada tiap akhir level permainan yang menunjukkan bahwa peserta didik "menang" atas level tersebut dan pada level terakhir terdapat "artefak" yang bisa jika dibuka berisi umpan balik pada peserta didik.

Aspek-aspek yang ada pada validitas permainan ini dikondisikan sedemikian rupa sehingga dapat mendukung suasana pembelajaran yang diharapkan (Sanjaya, 2012). Berdasarkan kategori dari Tabel 4 di atas dan hasil yang diperoleh dapat dikatakan permainan Red dan Ox valid sebagai media pembelajaran dikarenakan pada validitas diperoleh persentase $88,63 \%$ yang berada dalam kategori sangat valid. Hal ini berarti bahwa aspek-aspek yang 
ada dalam permainan ini telah valid sebagai media pembelajaran.

\section{Uji Coba Permainan}

Setelah dilakukan validasi permainan. Permainan dapat diujicobakan kepada para peserta didik. Uji coba permainan dilakukan pada 25 orang peserta didik yang belum mendapatkan materi penyetaraan reaksi redoks di SMAN 22 Surabaya. Uji Coba permainan ini bertujuan untuk mengetahui kepraktisan dan keefektifan permainan Red dan Ox. Permainan dikatakan praktis jika pengguna memberikan respon baik terhadap kebermanfaatan dan kemudahan perangkat pembelajaran (Nieveen, 2010). Keberhasilan proses pembelajaran berbasis permainan tidak bisa terlepas dari peserta didik itu sendiri karena pada akhirnya hal ini akan berhubungan langsung dengan output proses pembelajaran tersebut, seperti kepuasan, kegigihan serta hasil belajar/nilai para peserta didik (Koivisto, 2019). Untuk itu pada permainan diperlukan tanggapan para peserta didik sebagai pengguna dari permainan yang dinyatakan dalam bentuk angket respon. Pada angket respon yang diisi oleh peserta didik terdapat 6 tujuan yaitu ketertarikan terhadap permainan sebagai media pembelajaran $80 \%$, Keterbaruan permainan $90 \%$, keterbaruan ini menjadi penting dikarenakan adanya proses pengembangan dan inovasi baru yang diperlukan guna mendukung penerapan gaya belajar abad 21. Selain itu media pembelajaran juga dirancang dan disesuaikan dengan perkembangan teknologi informasi agar menarik dan mudah diakses oleh peserta didik guna mendapatkan materi pembelajaran (Yektyastuti, 2016). Kebermanfaatan permainan $91 \%$, sebagai sarana mencapai tujuan pembelajaran (Sanjaya, 2012) maka media pembelajaran dalam hal ini memiliki manfaat dan kegunaan yakni menyampaikan informasi yang berasal dari guru dan ditujukan kepada para peserta didik. Kemudahan dalam menggunakan permainan $88 \%$, Kebahasaan dalam permainan $88 \%$, Kesesuaian dengan karakteristik peserta didik 90\%, Permainan secara eksplisit bersifat rekreasi tetapi dapat juga bersifat pedagogik ketika tujuan utamanyletakan sentera adalah untuk merangsang pembelajaran yang signifikan (Anne, 2019). Dalam hal ini peserta didik sebagai pengguna harus dapat memahami penggunaan media tersebut dari aspek karakteristik dan juga kebahasaan. Permainan dapat digunakan sebagai alternatif yang efektif demi mendapatkan perhatian peserta didik yang dapat mereka gunakan untuk mempelajari topik atau keterampilan tertentut (Smaldino, 2014) dalam hal ini adalah kimia pada materi penyetaraan reaksi redoks.

Secara keseluruhan hasil angket respon yang telah diisi oleh peserta didik mendapatkan persentase sebesar $87,71 \%$ dalam kategori sangat praktis. Dengan didukung lembar observasi peserta didik yang berhasil menyelesaikan permainan dari awal hingga akhir sebesar $84 \%$ dengan total keseluruhan persentase hasil observasi peserta didik sebesar 92\%. Maka permainan Red dan Ox dapat dikatakan sangat praktis yang mana menunjukkan adanya keterbaruan, kebermanfaatan, kemudahan dalam penggunaan permainan serta kebahasahan yang ada dalam permainan ini praktis digunakan sebagai media pembelajaran.

Permainan dikatakan efektif jika peserta didik memahami perangkat tersebut dan dapat memengaruhi hasil evaluasi formatif (Nieveen, 2010). Hasil yang diharapkan berupa dampak akibat permainan sebagai media pembelajaran yang dikembangkan, dapat berupa hasil belajar, aktivitas selama permainan sebagai media pembelajaran, motivasi, minat dan keterampilan khusus lainnya. Dalam hal ini, permainan dikatakan efektif jika mengalami ketuntasan klasikal terpenuhi. Hasil belajar peserta didik secara singkat diuraikan pada tabel berikut.

\section{Tabel 5 Hasil belajar peserta didik}

\begin{tabular}{ccc}
\hline Aspek & Pretest & Posttest \\
\hline $\begin{array}{c}\text { Jumlah } \\
\text { Peserta didik }\end{array}$ & 25 & 25 \\
\hline $\begin{array}{c}\text { Nilai } \\
\text { terendah }\end{array}$ & 0 & 68,75 \\
\hline Nilai rata-rata & 54,75 & 87,50 \\
\hline Nilai tertinggi & 81,25 & 100,00 \\
\hline
\end{tabular}

Pada tabel 5 di atas dapat terlihat bahwa terdapat peningkatan skor peserta didik dan secara ringkas dapat dilihat pada grafik yang ada pada gambar 2 di bawah ini yang menunjukkan terdapat peningkatan persentase ketuntasan klasikal pada kelas tersebut dari $46 \%$ menjadi $96 \%$. Berdasarkan hal tersebut 
maka kelas tersebut dinyatakan tuntas secara klasikal dikarenakan kelas tersebut mendapatkan $\geq 85 \%$ peserta didik yang tuntas belajarnya (Smaldini, 2014).

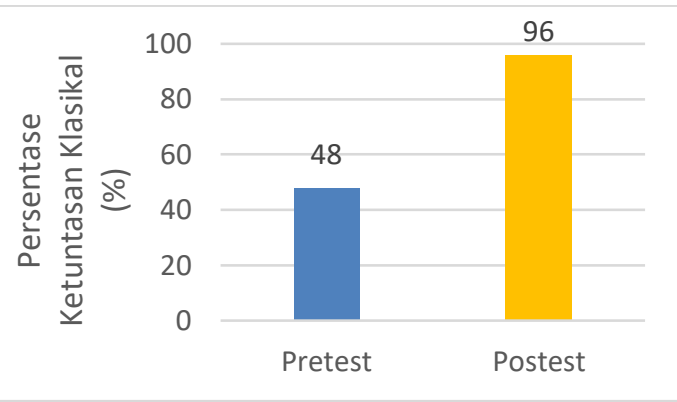

Gambar 2 Persentase ketuntasan klasikal

Pembelajaran berbasis permainan dapat digunakan untuk menarik perhatian peserta didik, membuat kondisi pembelajaran yang menyenangkan, serta memfasilitasi proses belajar peserta didik itu sendiri [Sánchez-Mena A. 2017, Lutfi, et, all., 2019). Pada materi penyetaraan reaksi redoks terdapat beberapa langkah-langkah yang perlu dipahami dan diingat oleh peserta didik untuk menyetarakan reaksi redoks yang dibagi dalam dua metode yakni metode setengah reaksi dan metode biloks (Dingrando, 2004). Untuk membantu peserta didik dalam memahami dan mengingat prosedur untuk menyetarakan reaksi redoks maka Permainan Red dan Ox dibuat sedemikian rupa sehingga menuntut peserta didik untuk dapat menjawab soal-soal yang ada guna mendapatkan kunci untuk menuju level selanjutnya. Alur permainan yang demikian akan menciptakan sebuah operan conditioning yang merupakan bentuk belajar dengan kehadiran respon yang berulang yang diikuti oleh sebuah konsekuensi tertentu, peserta didik disini akan berusaha mengulang respon yang akan memberikan dirinya konsekuensi yang menyenangnkan dalam hal ini mendapatkan kunci dan bisa menuju ke level selanjutnya (Slavin, 2009). Hal tersebut kemudian menjadi sebuah rangsangan dari luar yang ditangkap oleh peserta didik yang kemudian diproses dan dimasukkan kedalam memori jangka panjang peserta didik dan ketika dibutuhkan akan informasi tersebut akan diambil lagi (Schunk, 2012), sehingga peserta didik dengan mudah menjawab posttest karena telah menjadi terbiasa menjawab soal-soal materi penyetaraan reaksi redoks dalam permainan. Hal tersebut didukung oleh beberapa penelitian yang juga menunjukkan adanya peningkatan pada hasil belajar peserta didik sesudah menggunakan permainan pada materi tertentu sebagai media pembelajaran (Slamet, 2016, Rahmawati, 2018, Lutfi, 2019).

Untuk mendukung ketuntasan klasikal tersebut dilakukan uji paired t-test, namun sebelum itu dilakukan uji normalitas pada data skor yang diterima peserta didik menggunakan SPSS sehingga didapatkan perolehan hasil seperti pada tabel berikut

Tabel 6 Hasil Uji Normalitas Pretest dan Postest

\begin{tabular}{ccc}
\hline & Pretest & Posttest \\
\hline $\mathrm{N}$ & 25 & 25 \\
\hline $\begin{array}{c}\text { Kolmogorov- } \\
\text { Smirnov Z }\end{array}$ & 1.243 & 1.107 \\
\hline $\begin{array}{c}\text { Asymp. Sig. } \\
\text { (2-tailed) }\end{array}$ & .091 & .172 \\
\hline
\end{tabular}

Pada program SPSS P-Value ialah "Sig." Tabel 6 di atas menunjukkan nilai significance atau disingkat "Sig." Yang diperoleh sebesar 0.091 pada pretest dan 0.172 pada posttest yang keduanya $>0.05(\alpha)$ sehingga $H_{0}$ tertolak lalu bisa disimpulkan bahwa data tersebut terdistribusi normal sehingga dapat dilakukan analisis berikutnya menggunakan metode metode Paired Sampel t-test.

Analisis hasil pretest dan posttest peserta didik kemudian dianalisis dengan metode Paired Sampel t-test yang menggunakan SPPS kemudian didapatkan hasil sebagai berikut.

Tabel 7 Hasil Uji Paired Sampel t-test

\begin{tabular}{lllll}
\hline & & T & Df & $\begin{array}{l}\text { Sig. } \\
(2- \\
\text { tailed })\end{array}$ \\
\hline Pair 1 & $\begin{array}{l}\text { Pretest- } \\
\text { Postest }\end{array}$ & -6.626 & 24 & .000 \\
\hline
\end{tabular}

Pada Tabel 7 dapat diketahui nilai sig. Yang diperoleh sebesar 0.00 dan bisa dikatakan $<0.05 \quad(\alpha)$ sehingga $H_{0}$ tertolak kemudian dapat disimpulkan bahwa terdapat perbedaan skor rata-rata pada pretest dan posttest. Permainan dapat digunakan sebagai alat perantara dalam proses belajar dan mampu memberikan peningkatan hasil belajar peserta didik (López Carrillo, D. et al., 2019). Berdasarkan hal tersebut dapat dikatakan 
bahwa media permainan memiliki pengaruh terhadap hasil belajar peserta didik saat sebelum dan sesudah menggunakan media permainan Red dan Ox sehingga permainan Red dan Ox ini dapat dikatakan layak sebagai media pembelajaran.

\section{SIMPULAN DAN SARAN}

\section{Simpulan}

Berdasarkan uraian pada pembahasan dari hasil penelitian mengenai pengembangan permainan Red dan Ox dapat disimpulkan bahwa permainan Red dan Ox berbasis android yang telah dikembangkan sebagai media pembelajaran pada materi penyetaraan reaksi reduksi dan oksidasi dapat dikatakan layak kelayakan tersebut didasarkan pada 3 kriteria yang telah terpenuhi yakni validitas, kepraktisan, dan keefektifan yang menjadi beberapa poin sebagai berikut

1. Validitas permainan Red dan Ox berbasis android yang telah dikembangkan memperoleh persentase sebesar 88,63\% dalam kategori sangat valid.

2. Kepraktisan permainan Red dan Ox berbasis android yang telah dikembangkan didasarkan pada hasil angket respon yang diisi oleh peserta didik mendapatkan persentase sebesar $87,71 \%$ dalam kategori sangat praktis. Dengan didukung lembar observasi peserta didik yang berhasil menyelesaikan permainan dari awal hingga akhir sebesar $84 \%$ dengan total keseluruhan persentase hasil observasi peserta didik sebesar 92\%. Maka permainan Red dan Ox dapat dikatakan sangat praktis digunakan sebagai media pembelajaran.

3. ketuntasan klasikal pada kelas tersebut sebesar 96\% dan berdasarkan uji Paired Sampel t-test mendapatkan nilai sebesar 0.00 yang mana kurang dari $\alpha \quad(0.05)$ sehingga disimpulkan bahwa terdapat perbedaan pada skor rata-rata pada pretest dan posttest, sehingga permainan Red dan Ox berbasis android yang telah dikembangkan dapat dikatakan efektif.

\section{Saran}

Berdasarkan hasil penelitian dan kesimpulan yang telah dicapai, maka peneliti memberikan saran berupa masukan bagi peneliti berikutnya dan juga rekomendasi implikatif dari penelitian ini sebagai berikut.

1. Persentase ketuntasan klasikal setelah penggunaan permainan sebesar $96 \%$, yang menunjukkan bahwa permainan ini mampu memberikan dampak pada nilai/hasil belajar peserta didik. Untuk peneliti yang ingin memanfaatkan permainan ini dapat pula dilakukan penelitian untuk mengukur dampak lain yang didapatkan setelah penggunaan permainan ini selain hasil belajar dalam bentuk nilai, seperti halnya minat belajar, motivasi, rasa keingintahuan, self-efficacy maupun sikap lain pada peserta didik yang belum terukur pada penelitian ini

2. Berdasarkan perubahan persentase ketuntasan klasikal sebelum(48\%) dan sesudah(96\%) permainan ini digunakan maka permainan Red dan Ox ini dapat diaplikasikan sebagai sebagai alternatif media pembelajaran pada materi penyetaraan reaksi reduksi dan oksidasi.

3. Didalam permainan ini terdapat materi pada menu "belajar" dan juga latihan soal pada masing-masing levelnya, sehingga permainan ini dapat digunakan sebagai media pembelajaran daring/jarak jauh pada kondisi atau saat-saat tertentu dimana peserta didik maupun guru tidak dapat melakukan tatap muka secara langsung di dalam kelas seperti saat diberlakukannya situasi belajar di rumah oleh Kemendikbud di seluruh sekolah-sekolah di indonesia akibat adanya pandemi wabah Covid-19.

\section{DAFTAR PUSTAKA}

[1] Depdiknas. 2003. Undang-Undang Republik Indonesia Nomer 20 Tahun 2003 tentang Pendidikan Nasional. Jakarta: Depdiknas.

[2] Kementrian Pendidikan dan Kebudayaan. 2016. Permendikbud Nomor 22 Tahun 2016 tentang Stadar Proses Pendidikan Dasar dan Menengah. Jakarta: Kementrian Pendidikan dan Kebudayaan.

[3] Jauhar, M. 2010. Implementasi PAIKEM dari Behavioristik dan Konstruktivistik. Jakarta: Prestasi Pustaka.

[4] Dingrando, Laurel., Kathleen V. Gregg., Nicolas Hainen., Cheryl Wistrom. 2004. Chemistry : Matter and Change, Student 
Edition (Glancoe Chemistry) 2nd Edition. New York: McGraw-Hill Education.

[5] Sardiman, A.M. 2011. Interaksi \& Motivasi Belajar Mengajar. Jakarta: PT. Raja Grafindo Persada.

[6] Nordby, A. et al. 2016. The art of Gamification; Teaching Sustainability and System Thinking by Pervasive Game Development. The Electronic Journal of eLearning, 14(3), pp152-168.

[7] Slamet, F. \& Hidayah, R. 2016. Pengembangan Permainan Catch The Erlenmeyer Berbasis Android Sebagai Media Pembelajaran Pada Materi Tatanama Senyawa Kelas X SMA. Unesa Journal of Chemistry Education. Vol. 5, No. 3, 00. 605-702.

[8] Rahmawati, A. \& Lutfi, A. 2018. The Development of Super Chem Game Oriented Android as Instructional Media Electrolyte and Non Electrolyte. Journal of Chemistry Education Research, 2(1),1-10.

[9] Sari, S., \& Rahma, A. 2017. Using Android-Based Educational Game for Learning Colloid Material. Journal of Physics. Conf. Series 895.

[10] Sukmadinata, N. S. 2016. Metode Penelitian Pendidikan. Bandung: PT. Remaja Rosdakaya.

[11] Riduwan. 2012. Skala Pengukuran Variabel-Variabel Penelitian. Bandung: Alfabeta CV.

[12] Lutfi, A., Suyono \& Nur, M. 2014. Penilaian Permainan Bersarana Komputer sebagai Media Pembelajaran Ilmu Pengetahuan Alam, Proseding Seminar Nasional Kimia, ISBN: 978-6020951-00-3.

[13] Danim, S. 2010. Media Komunikasi Pendidikan. Jakarta: Bumi Aksara.

[14] Sanjaya, W. 2012. Perencanaan dan Desain Sistem Pembelajaran. Jakarta: Kencana Prenada Media Group.

[15] Nieveen, N., \& Plomp, T. 2010. An Introduction to Educational Design Research. Netherlands: SLO.

[16] Koivisto, J.\& Hamari, J.. 2019. The Rise of Motivational Information system: A Review of Gamification Research..
International Journal of Information Management, pp191-210.

[17] Yektyastuti, R., \& Ikhsan, J. 2016. Pengembangan Media Pembelajaran Berbasis Android pada Materi Kelarutan untuk Meningkatkan Performa Akademik Peserta Didik SMA. Jurnal Inovasi Pendidikan IPA, 88-99. https://journal.uny.ac.id/index.php/jipi/art icle/view/10289/8072, diakses tanggal 4 April 2020.

[18] Anne, Mary Sousa Lima \& Monteiro, Alvaro. 2019. Game-Based Application for Helping Students Review Chemical Nomenclatur in a Fun Way. Journal of Chemical Education. No. 96, 801-806.

[19] Smaldino, S., Lowther, D., \& Russel, J. 2014. Instructional Technology and Media for Learning: Teknologi dan Media untuk Belajar. Jakarta: Kencana.

[20] Trianto. 2010. Mendesain Model Pembelajaran Inovatif-Progresif. Jakarta: Kencana.

[21] Sánchez-Mena A., \& Martí-Parreño J. 2017. Drivers and Barriers to Adopting Gamification: Teachers' Perspectives. The Electronic Journal of e-Learning, 15(5), pp434-443.

[22] Lutfi, A. et al. 2019. Edutainment with Computer Game as a Chemistry Learning Media. Jurnal Penelitian Pendidikan Sains, 8(2), 1684-1689.

[23] Slavin, R. E. 2009. Educational Psychology: Theory and Practice. New Jersey: Pearson Education.

[24] Schunk, D, H. 2012. Learning Theories an Educational Perspective. Yogyakarta: Pustaka Belajar.

[25] Lutfi, A. \& Purwandani, N, A.. 2019. Minat Belajar dan Keberhasilan Belajar Partikel Penyusun Atom Dengan Media Pembelajaran Permainan Chem Man. Jurnal Pembelajaran Kimia, Vol. 4, No. 1, hal. 39-50.

[26] López Carrillo, D. et al., 2019. Using Gamification in a Teaching Innovation Project at the University of Alcalá: A New Approach to Experimental Science Practices. The Electronic Journal of eLearning, 17(2), pp. 93-106. 